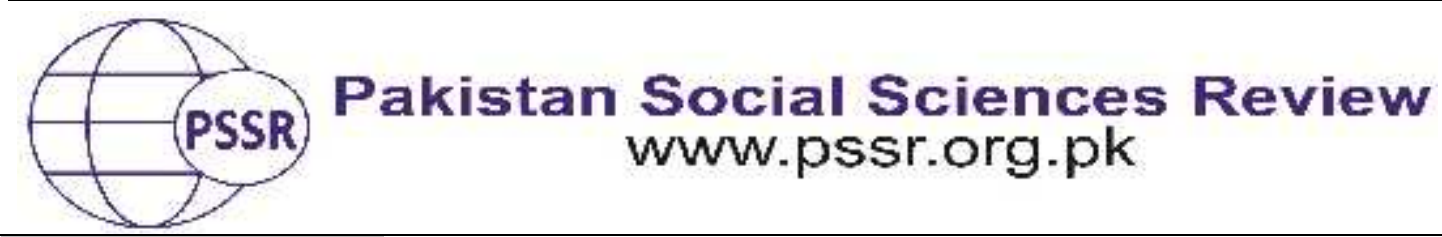

RESEARCH PAPER

\title{
Importance of Employee Engagement at Workplace: Literature Review and Future Directions
}

\author{
Bilal Khalid ${ }^{1}$ Dr. Faisal Shafique Butt* ${ }^{2}$ Maryum Qayyum Satti ${ }^{3}$
}

1. Ph.D. Scholar, Department of Management Sciences, Riphah International University, Islamabad, Pakistan

2. Assistant Professor, Department of Computer Sciences, COMSATS University Islamabad, Wah Campus, Pakistan

3. MS Scholar, Department of Management Sciences, Riphah International University, Islamabad, Pakistan

\begin{tabular}{|c|c|}
\hline PAPE & ABSTRACT \\
\hline 1,2021 & $\begin{array}{l}\text { The present review article highlights noticeable aspects of } \\
\text { employee engagement at workplace. The primary purpose of } \\
\text { the study is to document all possible literature related to } \\
\text { employee engagement in an organized manner in this study. } \\
\text { For this purpose, researchers carried out detailed analyzes of }\end{array}$ \\
\hline rds: & $\begin{array}{l}\text { almost } 58 \text { articles spanning over } 15 \text { years. Furthermore, various } \\
\text { research databases/journals searched and only empirical } \\
\text { studies selected for review purpose. On the basis of review of } \\
\text { articles, researchers also proposed that in future, more studies }\end{array}$ \\
\hline esponding & $\begin{array}{l}\text { should examine the employee engagement levels in } \\
\text { organizational settings considering the phenomenon of moral } \\
\text { disengagement. }\end{array}$ \\
\hline
\end{tabular}

\section{Introduction}

In this present age of globalization and where organizations are becoming more dynamics in its nature due to various factors like technology and culture, research study(Macey et al., 2011)highlighted that employees engagement plays its imperative role in competitive advantage at workplace. The role of employees at workplace is becoming more imperative especially in case of service sector(de Mattos et al., 2019). In the current age of globalization, engaging employees at workplace is becoming more hectic for employers for effective and smooth working(Chandani et al., 2016). Engagement of employees plays its pivotal role at workplace and also leads towards their career development. Research studies highlight imperative nature of employee engagement in organizational settings(Arrowsmith \& Parker, 2013; Christian et al., 2011; Crawford et al., 2010; Lee, 2012; Macey \& Schneider, 2008; Reissner \& Pagan, 2013; Remo, 2012; Saks, 2006; Van 
Rooy et al., 2011; Wollard \& Shuck, 2011). According to researchers(Arrowsmith \& Parker, 2013; Crawford et al., 2010; Truss et al., 2013), the concept of employee engagement is always under focus, but in academic settings it is always presented in new way.

\section{Operational Definitions}

It is "all about the willingness and ability of the employee to give sustained discretionary effort to help their organization succeed" (Cook, 2008; cited O'Carroll, 2015). The most inclusive definition of employee engagement documented as "a positive fulfilling, work-related state of mind that is characterized by vigor, dedication and absorption, whereby vigor refers to high levels of energy and metal resilience while working. The willingness to invest effort in one's work and persistence even in the face of difficulties; dedication refers to being strongly involved in one's work, and experiencing a sense of significance, enthusiasm, inspiration, pride and challenge; and absorption refers to being fully concentrated and happily engrossed in one's work, whereby time passes quickly and one has difficulties with detaching oneself from work" (Schaufeli, Salanova, González-Romá, \& Bakker, 2002, p. 74). Furthermore, employees' engagement can be documented as "full employee engagement represents an alignment of maximum satisfaction for the individual with maximum contribution for the organization"(Rice, Marlow, \& Masarech, 2012, p. 4).

\section{Literature Review}

In the present age of technological advancement and when organizations are becoming diverse in their working, the engagement of employees' at best possible level within the organizational context is very crucial. The impression of engagement of employees is the "Holy Grail" within workplace setting for organizational effectiveness(Church, 2013; Hart, 2016). (Rani \& Punitha, 2015) documented that in the current era of globalization, organizations are more focusing on human capital and trying their best to engage employees within work setting at best possible extent, as they know that engaged employees will work better, which will result in enhanced organizational effectiveness(Chughtai \& Lateef, 2015).Chandani et al., (2016) documented that during the phase of digging out the literature on employee engagement, studies highlighted that this construct is linked with various employees' attitudinal and behavioral factors like talent management, career development, employee empowerment, performance management, emotional factors and with turnover intention, productivity, satisfaction(Brunetto et al., 2012; Chat-Uthai, 2013; Harter et al., 2002; Markos \& Sridevi, 2010; Moreland, 2013; Yalabik et al., 2013).

Researchers(De Clercq et al., 2014; Moreira, 2013)highlighted that due to high engagement level among employees, their individual behaviors movepositively towards organizational outcome in an effective manner and reduces un-comfort zone at workplace. The concept of engagement among employees at workplace is 
linked with various individual behaviors (Rasheed et al., 2013). Basically it is a psychological perspective that happy employee are attached more than others with their work and organizations(Albrecht, 2010; Anandhi \& Perumal, 2013; Kular et al., 2008; Markos \& Sridevi, 2010).

(Andrew \& Sofian, 2012) informed that in the era of 21st century, organizations are focusing on their human talent for best outcome in organizational settings through engaging employees effectively. Although the engagement of employees is linked with various individual behaviors at workplace, it is also considered that through this concept both (employers/employees) are synchronized with each other for organizational goals(Fleck \& Inceoglu, 2010; González-Romá et al., 2006; Newman et al., 2010).

The article titled "Psychological Conditions of Personal Engagement and Disengagement at work" (Kahn, 1990) supported the working of(Goffman, 1961) and highlighted that through the dimensional effects of safety: "without fear and negative consequences to self-image, status or career", availability: "sense of possessing the physical, emotional resources necessary", and meaningfulness: "sense of return on involvements of self-in-role performance" (pp. 705), the concept of engaged workforce can be understood in an organized and smooth manners.

A decade before the concept of employee engagement again started being discussed widely, but in recent years' imperative nature of this concept got attention within literature as well as in practical approach. Although, the phenomenon of employee engagement is an individual perspective but is more effective than the other related concepts/constructs(Shaw \& Bastock, 2005; Woodruffe, 2006). Employees are categorized into three groups ("engaged employees, non-engaged employees, and actively-disengaged employees") as documented by (Coffman, 2000).

Researcher(Kahn, 1990) in his article "Psychological Conditions of Personal Engagement and Disengagement at Work", introduced the concept of engagement of employees at workplace(Kular et al., 2008; Lee, 2012; Simpson, 2009). According to (Kahn, 1990) engagement of employees is defined as "the harnessing of organization member's selves to their roles; in engagement employees express themselves physically, cognitively and emotionally during role performance" (pp. 694).

According to(Saks, 2006)employee engagement is a social phenomenon and can be developed and bi-furcated engagement at two levels individual and organizational. He defined engagement of employees as "a distinct and unique construct consisting of cognitive, emotional, and behavioral components associated with individual role performance" (p. 602). Later, (Maslach et al., 2001)defined and explained engagement of employees through their research work as "a persistent positive affective state characterized by high levels of activation and pleasure" ( $p$. 417), in 2002 researchers(Schaufeli et al., 2002)further worked on the basis of Maslach's work and concludedengagement of employeesas "positive fulfilling". Researchers(Harter et al., 2002; Jeung, 2011; Shuck \& Wollard, 2010) defined 
engagement of employees as "individual's involvement and satisfaction with as well as enthusiasm for work" (p. 269) and study of employee engagement at business level unit levels in organizational settings respectively.

\section{Dimensionality of Employee Engagement}

The phenomenon of employees' engagement at workplace is based on three facets (vigor, dedication, \& absorption). Vigor: deals with individual's physical energy, mentally resilience, and continuous efforts toward his/her own job(Rayton \& Yalabik, 2014). In workplace settings, job nature/role plays its role to augment engagement levels among employees, and engaged employees performed better than the others(Kahn, 1990). Dedication: According to researchers (Rayton \& Yalabik, 2014) dedication of employees' is all about their devotion and involvement in their jobs at workplace. (Kelman, 1958) explained that in terms of dedication, employees put their emotional and psychical efforts towards their work, and due to this, it is assumed that emotionally charges employees behave in an effective manner in organizations. Absorption: This dimensions deals with sense of employees' detachment from you environment at workplace (Rayton \& Yalabik, 2014). This element is related with attention \& cognition(Kahn, 1990; Rothbard, 2001)and focused on work-role behaviors among employees.

\section{Levels of Employees}

Employees, according to their engagement levels, are categorized into three domains in organizational settings(Coffman, 2000). Engaged workforce put their best efforts towards work at workplace, but unfortunately this category of employees is very rarely can be seen at workplaces(Keating \& Heslin, 2015; Sanford \& Coffman, 2002). Furthermore, researchers(Sanford \& Coffman, 2002)supplemented Coffman's work that mostly employees are not engaged and they come under dis-engaged domain, this type of employees only increases the cost of the organization and the resultant organizations do not want to retain them(Karsan, 2007). Actively disengaged employees try and manipulate to other employees from their work(Coffman, 2000), known as "cave dwellers" (Vazirani, 2007).

\section{Key Driving Forces}

The phenomenon of engagement of employees is based on various factors, and so many factors shape this concept for individuals at workplace for overall organizational productivity and effectiveness(Chaudhary et al., 2016; Sarangi \& Vats, 2015). Some constructs/elements like meaningful work/positive working environment/trust \& growth opportunity/hands on engagement(Bersin, 2015) and job-characteristics/organizational support/justice/recognition(Kumar \& Swetha, 2011)are considered as driving forces of employee engagement. Researcher(Vazirani, 2007) listed some important drivers(Basbous, 2011) that make the employees engaged. 


\section{Antecedents and Consequences}

The building of engaged workforce is an uphill task within work settings. Researchers (Alfes et al., 2013) documented that engagement levels of employees is influenced by various related factors, but these factors are more close / related with disengaged employees rather than engaged(Boon \& Kalshoven, 2014). Employee engagement phenomenon is related with performance of individuals(Abu Bakar, 2013), while this concept is also different but related from psychological wellbeing(Robertson \& Flint-Taylor, 2009). The researcher (Robertson \& Flint-Taylor, 2009)documented antecedents / consequences of employees' engagement in tabulated form for better understanding of the phenomenon in different settings.

\section{Supporting Theories}

The theory presented by two researchers (Deci \& Ryan, 1985) was based on intrinsic/extrinsic factors of motivation. These factors result in introjections, identification, and integration approaches(Ryan \& Deci, 2000). According to them, it is based on three factors (need for autonomy, competence, and relatedness). This theory helps to motivate individuals towards their engagement at work through intrinsic motivational factors(Knight, 2016). Researchers(Richard \& Oldham, 1976)proposed and presented the JCR theory. It may be defined as "the relationship between job characteristics and individual responses to work, the theory specifies the task condition in which individuals are predicted to proper at their work" (Faturochman, 1997).

COR theory highlights that employees/individuals put their efforts in terms of skills towards their work for achievement of goals(Albrecht, 2010). There is linkage between employees behavior and resource utilization in organizational settings. Albrecht (2010) documented that COR theory is based on "those entities that either are centrally valued in their own right, or act as means to obtain centrally valued ends" (pp.307).

This theory presented and explained by(Fredrickson, 1998, 2001)that in terms of positive emotional skills as it is genetic process, employees work for the betterment of the organization. This model highlights that individuals required necessary physical and emotional skills at workplace(Li \& Mao, 2014). JDR model is also the bases of work engagement model proposed by(Bakker \& Demerouti, 2007; Demerouti et al., 2001).

\section{Measurement of Employee Engagement}

The comprehensive scale used for measuring, employee engagement is known as "Utrecht Work Engagement Scale" developed by researchers(Schaufeli et al., 2002)based on three dimensions (17-items). 


\section{List of Particular Journals}

For the present review, researchers have gone through from different reputed research journal databases to enhance the base of the research.

\section{Conclusion}

On the basis of earlier studies on employee engagement within various organizational contexts, researchers concluded that employee engagement can be linked with behavioral and attitudinal aspects and these observations also aligned with researches carried out by different researchers(Bakker et al., 2014; Sonnentag et al., 2010). They documented that employee engagement is a fluctuated phenomenon with respect to individuals, time and organizational environment. Employee engagement phenomenon highlighted that job crafting behaviors directly leads with employee engagement in work settings(Petrou et al., 2012).Research studies highlighted that employee engagement is studied in various context and phenomenon like top down approach of Human Resource System(Bakker \& Albrecht, 2018), ability-motivation-opportunity model(Saks, 2006), organizational culture(Denning, 2013), adaptive leadership styles(Breevaart et al., 2014; Caulfield \& Senger, 2017; Ghadi et al., 2013; Yammarino et al., 2012)and with performance(Gordon et al., 2018; Van Wingerden et al., 2017).

\section{Recommendations}

In the current age and coming future, the engaging nature of employees at workplace is going to be linked with technological aspects and future research is going to be focus on Big Data, Artificial Intelligence and different work settings/context like Lean-Agile-Virtual through the support of theories and models like Job Demand Resource Model (Power, 2017).Researchers(King et al., 2015)knew that through the usage of Big Data, engagement levels of employees can be maintained and manager-employee relationship can easily understood in effective manner at workplace.

In future, further studies should dig-out more perspectives of the nature of employee engagement in organizational settings, to document empirical literature and sought of some meta-analysis within specific industry. No doubt, it is ever changing phenomenon, and with nature of business environment and cultural and technological aspects it can be changed. So in a nutshell, more attention should be paid on its dynamic nature in organizational settings and it should also be studied along-with moral disengagement factors within specific context. 


\section{References}

Abu Bakar, R. (2013). Understanding factors influencing employee engagement: A study of the financial sector in Malaysia.

Albrecht, S. L. (2010). Employee engagement: 10 key questions for research and practice.

Alfes, K., Truss, C., Soane, E. C., Rees, C., \& Gatenby, M. (2013). The relationship between line manager behavior, perceived HRM practices, and individual performance: Examining the mediating role of engagement. Human Resource Management, 52(6), 839-859.

Anandhi, K., \& Perumal, R. (2013). Job satisfaction in logistics sector: A review and research agenda. International Journals of Marketing and Technology, 3(5), 114-126.

Andrew, O. C., \& Sofian, S. (2012). Individual factors and work outcomes of employee engagement. Procedia-Social and Behavioral Sciences, 40, 498-508.

Arrowsmith, J., \& Parker, J. (2013). The meaning of 'employee engagement'for the values and roles of the HRM function. The International Journal of Human Resource Management, 24(14), 2692-2712.

Bakker, A. B., \& Albrecht, S. (2018). Work engagement: current trends. Career Development International.

Bakker, A. B., \& Demerouti, E. (2007). The job demands-resources model: State of the art. Journal of Managerial Psychology.

Bakker, A. B., Demerouti, E., \& Sanz-Vergel, A. I. (2014). Burnout and work engagement: The JD-R approach.

Basbous, O. K. (2011). Antecedents of employee engagement. Published Thesis, University of Malaysia.

Bersin, J. (2015). Becoming irresistible. Deloitte Review, 16, 146-163.

Boon, C., \& Kalshoven, K. (2014). How high-commitment HRM relates to engagement and commitment: The moderating role of task proficiency. Human Resource Management, 53(3), 403-420.

Breevaart, K., Bakker, A., Hetland, J., Demerouti, E., Olsen, O. K., \& Espevik, R. (2014). Daily transactional and transformational leadership and daily employee engagement. Journal of Occupational and Organizational Psychology, 87(1), 138-157.

Brunetto, Y., Teo, S. T. T., Shacklock, K., \& Farr-Wharton, R. (2012). Emotional intelligence, job satisfaction, well-being and engagement: explaining organisational commitment and turnover intentions in policing. Human Resource Management Journal, 22(4), 428-441. 
Caulfield, J. L., \& Senger, A. (2017). Perception is reality: Change leadership and work engagement. Leadership \& Organization Development Journal.

Chandani, A., Mehta, M., Mall, A., \& Khokhar, V. (2016). Employee engagement: A review paper on factors affecting employee engagement. Indian Journal of Science and Technology, 9(15), 1-7.

Chat-Uthai, M. (2013). Leveraging employee engagement surveys using the turnover stimulator approach: A case study of automotive enterprises in Thailand. International Journal of Business and Management, 8(6), 16.

Chaudhary, S., Kumar, K. H. A., \& Dr, K. H. (2016). Drivers of employee engagement-a conceptual study. International Journal of World Research, 1(26), 1319.

Christian, M. S., Garza, A. S., \& Slaughter, J. E. (2011). Work engagement: A quantitative review and test of its relations with task and contextual performance. Personnel Psychology, 64(1), 89-136.

Chughtai, M. W., \& Lateef, K. (2015). Role of emotional intelligence on employees performance in customer services: A case study of telecom sector of Pakistan. International Journal of Advance Research in Computer Science and Management Studies, 3(2), 101-108.

Church, A. H. (2013). Engagement is in the eye of the beholder: Understanding differences in the OD vs. talent management mindset. OD Practitioner, 45(2), 4248.

Coffman, C. (2000). Is Your Company Bleeding Talent. How to Become a True "Employer of Choice". The Gallup Management Journal, 74-85.

Cook, S. (2008). The essential guide to employee engagement: better business performance through staff satisfaction. Kogan Page Publishers.

Crawford, E. R., LePine, J. A., \& Rich, B. L. (2010). Linking job demands and resources to employee engagement and burnout: a theoretical extension and meta-analytic test. Journal of Applied Psychology, 95(5), 834.

De Clercq, D., Bouckenooghe, D., Raja, U., \& Matsyborska, G. (2014). Unpacking the goal congruence-organizational deviance relationship: The roles of work engagement and emotional intelligence. Journal of Business Ethics, 124(4), 695-711.

de Mattos, C. S., Fettermann, D. C., \& Cauchick-Miguel, P. A. (2019). Service modularity: literature overview of concepts, effects, enablers, and methods. The Service Industries Journal, 1-22. 
Deci, E. L., \& Ryan, R. M. (1985). Intrinsic motivation and self-determination in human behavior: Springer Science \& Business Media.

Demerouti, E., Bakker, A. B., Nachreiner, F., \& Schaufeli, W. B. (2001). The job demands-resources model of burnout. Journal of Applied Psychology, 86(3), 499.

Denning, S. (2013). Why Agile can be a game changer for managing continuous innovation in many industries. Strategy $\mathcal{E}$ Leadership.

Faturochman, M. A. (1997). The job characteristics theory: A review. Buletin Psikologi UGM, December 2 nd1997.

Fleck, S., \& Inceoglu, I. (2010). A comprehensive framework for understanding and predicting engagement. The Handbook of Employee Engagement: Perspectives, Issues, Research, E Practice, 31-42.

Fredrickson, B. L. (1998). What good are positive emotions? Review of General Psychology, 2(3), 300-319.

Fredrickson, B. L. (2001). The role of positive emotions in positive psychology: The broaden-and-build theory of positive emotions. American Psychologist, 56(3), 218.

Ghadi, M. Y., Fernando, M., \& Caputi, P. (2013). Transformational leadership and work engagement. Leadership \& Organization Development Journal.

Goffman, E. (1961). Encounters: Two studies in the sociology of interaction. Ravenio Books.

González-Romá, V., Schaufeli, W. B., Bakker, A. B., \& Lloret, S. (2006). Burnout and work engagement: Independent factors or opposite poles? Journal of Vocational Behavior, 68(1), 165-174.

Gordon, H. J., Demerouti, E., Le Blanc, P. M., Bakker, A. B., Bipp, T., \& Verhagen, M. A. M. T. (2018). Individual job redesign: Job crafting interventions in healthcare. Journal of Vocational Behavior, 104, 98-114.

Hart, A. J. (2016). Exploring the Influence of Management Communication Behaviors on Employee Engagement.

Harter, J. K., Schmidt, F. L., \& Hayes, T. L. (2002). Business-unit-level relationship between employee satisfaction, employee engagement, and business outcomes: a meta-analysis. Journal of Applied Psychology, 87(2), 268.

Jeung, C. (2011). The concept of employee engagement: A comprehensive review from a positive organizational behavior perspective. Performance Improvement Quarterly, 24(2), 49-69. 
Kahn, W. A. (1990). Psychological conditions of personal engagement and disengagement at work. Academy of Management Journal, 33(4), 692-724.

Karsan, R. (2007). Calculating the cost of turnover. Employment Relations Today, 34(1), 33-36.

Keating, L. A., \& Heslin, P. A. (2015). The potential role of mindsets in unleashing employee engagement. Human Resource Management Review, 25(4), 329-341.

Kelman, H. C. (1958). Compliance, identification, and internalization: Three processes of attitude change. Journal of Conflict Resolution, 51-60.

King, E. B., Tonidandel, S., Cortina, J. M., \& Fink, A. A. (2015). Building understanding of the data science revolution and IO psychology. In Big Data at Work (pp. 15-30). Routledge.

Knight, A. W. (2016). A self-determination theory-based analysis of the effects of clinical instructor behavior on student clinical engagement.

Kular, S., Gatenby, M., Rees, C., Soane, E., \& Truss, K. (2008). Employee engagement: A literature review.

Kumar, D. P., \& Swetha, G. (2011). A prognostic examination of employee engagement from its historical roots. International Journal of Trade, Economics and Finance, 2(3), 232.

Lee, J. (2012). Antecedents and consequences of employee engagement: Empirical study of hotel employees and managers. Kansas State University.

Li, L., \& Mao, S. (2014). Moderating effects of proactive personality on factors influencing work engagement based on the job demands-resources model. Social Behavior and Personality: An International Journal, 42(1), 7-15.

Macey, W. H., \& Schneider, B. (2008). The meaning of employee engagement. Industrial and Organizational Psychology, 1(1), 3-30.

Macey, W. H., Schneider, B., Barbera, K. M., \& Young, S. A. (2011). Employee engagement: Tools for analysis, practice, and competitive advantage (Vol. 31). John Wiley \& Sons.

Markos, S., \& Sridevi, M. S. (2010). Employee engagement: The key to improving performance. International Journal of Business and Management, 5(12), 89.

Maslach, C., Schaufeli, W. B., \& Leiter, M. P. (2001). Job burnout. Annual Review of Psychology, 52(1), 397-422. 
Moreira, M. E. (2013). Importance of Employee Engagement. In Being Agile (pp. 3344). Springer.

Moreland, J. (2013). Improving job fit can improve employee engagement and productivity. Employment Relations Today, 40(1), 57-62.

Newman, D. A., Joseph, D. L., \& Hulin, C. L. (2010). Job attitudes and employee engagement: Considering the attitude "A-factor." The Handbook of Employee Engagement: Perspectives, Issues, Research, and Practice, 43-61.

O'Carroll, B. (2015). An examination of the key drivers influencing employee engagement in a declining outsourcing company in Dublin. Dublin, National College of Ireland.

Petrou, P., Demerouti, E., Peeters, M. C. W., Schaufeli, W. B., \& Hetland, J. (2012). Crafting a job on a daily basis: Contextual correlates and the link to work engagement. Journal of Organizational Behavior, 33(8), 1120-1141.

Rani, A. S., \& Punitha, K. (2015). A Study on employee engagement in Chettinad Cement Corporation Limited, Puliyur, Karur. International Journal of Management, 6(1), 646-655.

Rasheed, A., Khan, S., \& Ramzan, M. (2013). Antecedents and consequences of employee engagement: The case of Pakistan. Journal of Business Studies Quarterly, 4(4), 183.

Rayton, B. A., \& Yalabik, Z. Y. (2014). Work engagement, psychological contract breach and job satisfaction. The International Journal of Human Resource Management, 25(17), 2382-2400.

Reissner, S., \& Pagan, V. (2013). Generating employee engagement in a publicprivate partnership: Management communication activities and employee experiences. The International Journal of Human Resource Management, 24(14), 27412759 .

Remo, N. (2012). Comparing two models of employee engagement: An examination of antecedents and outcome variables.

Rice, C., Marlow, F., \& Masarech, M. A. (2012). The engagement equation: Leadership strategies for an inspired workforce. John Wiley \& Sons.

Richard, H. J., \& Oldham, G. (1976). Motivation through the design of work: Test of a theory. Organizational Behavior and Human Performance, 16(2), 250-279.

Robertson, I. T., \& Flint-Taylor, J. (2009). Leadership, psychological well-being, and organizational outcomes. In The Oxford Handbook of Organizational Well Being.

Rothbard, N. P. (2001). Enriching or depleting? The dynamics of engagement in work and family roles. Administrative Science Quarterly, 46(4), 655-684. 
Ryan, R. M., \& Deci, E. L. (2000). Self-determination theory and the facilitation of intrinsic motivation, social development, and well-being. American Psychologist, 55(1), 68 .

Saks, A. M. (2006). Antecedents and consequences of employee engagement. Journal of Managerial Psychology.

Sanford, B., \& Coffman, C. (2002). The high cost of disengaged employees. Gallup Management Journal.

Sarangi, S., \& Vats, A. (2015). Role of emotional intelligence on employee engagement: A study among Indian professionals. International Journal of Business and Management, 10(6), 224.

Schaufeli, W. B., Salanova, M., González-Romá, V., \& Bakker, A. B. (2002). The measurement of engagement and burnout: A two sample confirmatory factor analytic approach. Journal of Happiness Studies, 3(1), 71-92.

Shaw, K., \& Bastock, A. (2005). Employee engagement: How to build a highperformance workforce. Chicago: Melcrum Publishing Linited. Sonnentag, S.(2003), Recovery, Work Engagement, and Proactive Behavior: A New Look at the Interface between Nonwork and Work. Journal of Applied Psychology, 88(3), 518-528.

Shuck, B., \& Wollard, K. (2010). Employee engagement and HRD: A seminal review of the foundations. Human Resource Development Review, 9(1), 89-110.

Simpson, M. R. (2009). Engagement at work: A review of the literature. International Journal of Nursing Studies, 46(7), 1012-1024.

Sonnentag, S., Dormann, C., \& Demerouti, E. (2010). Not all days are created equal: The concept of state work engagement. Work Engagement: A Handbook of Essential Theory and Research, 25-38.

Truss, C., Shantz, A., Soane, E., Alfes, K., \& Delbridge, R. (2013). Employee engagement, organisational performance and individual well-being: exploring the evidence, developing the theory. Taylor \& Francis.

Van Rooy, D. L., Whitman, D. S., Hart, D., \& Caleo, S. (2011). Measuring employee engagement during a financial downturn: business imperative or nuisance? Journal of Business and Psychology, 26(2), 147-152.

Van Wingerden, J., Bakker, A. B., \& Derks, D. (2017). Fostering employee well-being via a job crafting intervention. Journal of Vocational Behavior, 100, 164-174.

Vazirani, N. (2007). Employee engagement. SIES: College of Management Studies Working Paper Series. 
Wollard, K. K., \& Shuck, B. (2011). Antecedents to employee engagement: A structured review of the literature. Advances in Developing Human Resources, 13(4), 429-446.

Woodruffe, C. (2006). The crucial importance of employee engagement. Human Resource Management International Digest.

Yalabik, Z. Y., Popaitoon, P., Chowne, J. A., \& Rayton, B. A. (2013). Work engagement as a mediator between employee attitudes and outcomes. The International Journal of Human Resource Management, 24(14), 2799-2823.

Yammarino, F. J., Salas, E., Serban, A., Shirreffs, K., \& Shuffler, M. L. (2012). Collectivistic leadership approaches: Putting the "we" in leadership science and practice. Industrial and Organizational Psychology, 5(4), 382-402. 